\title{
Intraperitoneal and local ozone applications in veterinary oncology treatment [abstract]
}

\section{Adriano Caquetti}

ABOZ (Brazilian Association of Ozone Therapy) advisor, ABO3 Vet (Brazilian Association of Veterinary Ozone

Therapists) president, and CEO of Ozoniovet, Brazil's first specialized ozone therapy veterinary clinic

\section{ABSTRACT}

\section{OPEN ACCESS}

\section{Citation}

Caquetti A. Intraperitoneal and local ozone applications in veterinary oncology treatment [abstract]. Proceedings of The World Conference on Ozone Therapy in Medicine, Dentistry and Veterinary. Ancona (Italy). September 22nd - 23rd - 24th , 2017. J Ozone Ther. 2019:3(4):7-8. doi: 10.7203/jo3t.3.4.2019.15397

Academic Editor

Jose Baeza-Noci,

School of Medicine, Valencia

University, SPAIN

\section{Editor}

World Federation of Ozone Therapy, Bolgna, ITALY

\section{Received}

June 17, 2019

\section{Accepted}

December 08, 2019

Published

December 30, 2019

\section{Intellectual Property}

Adriano Caquetti.

This is an open access article distributed under the terms of the Creative Commons Attribution License (CC BY 4.0), which permits unrestricted use, distribution, and reproduction in any medium, provided the original author and source are credited.

\section{Author Information}

Phone: +55 (11) 99973-4961

E-Mail: acaquetti@yahoo.com.br
The elevated incidence of some non treatable, or with low therapeutic results, side effects in certain areas of veterinary medicine such as oncology, orthopaedics, wounds and infections in dogs, cats, and horses is notoriously reported and differentiated in several infirmities. These side effects manifest in symptoms acting as locomotor disability, pain, and in some cases, they result in a great loss of life quality in animals and their owners alike.

Therefore, intraperitoneal and local ozone applications have brought relevant results and are now being used as complementary or, in certain cases, only treatment. The goal of this lecture is to show the use as well as the results and techniques used in oncological pathologies treated with intraperitoneal and local ozone applications which did not respond ,or had low therapeutic results, to conventional veterinary treatment. All this demonstrates that Intraperitoneal as well as local ozone applications are powerful tools available to veterinarians in order to promote relief, comfort, or, possibly, cure to animals.

\section{References:}

1. Schulz S, Haussler U, Mandic R, et al. Treatment with ozone/oxygenpneumoperitoneum results in complete remission of rabbit squamous cell carcinoma, Int. J. Cancer. 2008;122,2360-2367.

2. Dunne AA, Mandic R, Ramaswamy A, et al. Lymphogenic metastatic spread of auricular VX2 carcinoma in New Zealand white rabbits. Anticancer Res 2002;22:3273-3279.

3. Schaefer C, Kim GG, Albers A, Hoermann K, Myers EN, Whiteside TL. Characteristics of CD41CD251 regulatory $T$ cells in the periph- eral circulation of patients with head and neck cancer. $\mathrm{Br} J$ Cancer 2005;92:913-920.

4. Schneider MR, Tang DG, Schirner M, Honn KV. Prostacyclin and its analogues: antimetastatic effects and mechanisms of action. Cancer Metastasis Rev. 1994;13:349-364.

5. Bhardwaj $\mathrm{N}$. Harnessing the immune system to treat cancer. $\mathrm{J}$ Clin Invest. 2007;117:1130-1136

6. Lin WW, Karin M. A cytokine-mediated link between innate immunity, inflammation, and cancer. J Clin Invest 2007;117:1175-1183.

7. Schulz S, Rodriguez ZZ, Mutters R, Menendez S, Bette M. Repetitive pneumoperitoneum with ozonized oxygen as a preventive in lethal polymicrobial sepsis in rats. Eur Surg Res. 2003;35:26-34. 
8. van Es RJ, Baselmans AH, Koten JW, Van Dijk JE, Koole R, Den Otter W. Perilesional IL-2 treatment of a VX2 head-and-neck cancer model can induce a systemic anti-tumour activity. Anticancer Res. 2000;20:41634170.

9. Neudecker J, Sauerland S, Neugebauer E, et al. The European Association for Endoscopic Surgery clinical practice guideline on the pneumoperitoneum for laparoscopic surgery. Surg Endosc. 2002;16:1121-1143.

10. Hicks AM, Riedlinger G, Willingham MC, et al. Transferable anticancer innate immunity in spontaneous regression/complete resistance mice. Proc Natl Acad Sci USA. 2006;103:7753-7758. 